\title{
Using Dialogue Journal to Improve Students' Writing Proficiencies
}

\author{
Yunita Widya Hapsari, Gunarso Susilohadi, Dwi Elyono
}

\author{
English Education Department \\ Teacher Training and Education Faculty \\ Sebelas Maret University of Surakarta
}

Email: yunitahapsari15@gmail.com

\begin{abstract}
Dialogue journal is perceived as an effective technique for teaching writing. This article aims at reporting a study on the use of Dialogue journal to improve students' writing proficiencies. The objectives of the research were to know how dialogue journal can be implemented effectively to improve students' writing proficiencies and to know to what extent dialogue journal can improve their writing proficiencies. A classroom action research was conducted in a group of students in one of state junior high school in Surakarta. The data collected were qualitative and quantitative. The qualitative data were obtained from observations and interviews, while the quantitative data were collected from tests. The findings of the research show that (1) dialogue journal can be implemented effectively by taking some considerations; and (2) the implementation of dialogue journal could improve the students' writing proficiencies and the classroom situation. This was proven by the improvement of the students' writing mean scores and their attitude toward the learning. They became more active and motivated.
\end{abstract}

Keywords: writing proficiencies, dialogue journal, classroom action research

\section{INTRODUCTION}

Dialogue journal is perceived as an effective technique in teaching writing which can motivate the students to practice writing frequently. As cited from Brown (2004) Dialogue journal is generally an interactive conversation between a teacher and the students which is written in a notebook frequently (weekly or biweekly) about a topic that interests them both, as a regular practices for the students in writing. The role of the teacher is giving feedbacks and comments on the students' work with correct grammatical forms and structure as a model for the students (Forouton, Noordin \& Hamzah, 2013).

According to Reid (1993, p.163), Dialogue journal is a journal written by students and teacher, they carry a conversation and interaction in the journal.
The teacher gives responses for the students' work without correcting the form since the focus of dialogue journal are communication and fluency. Dialogue Journal provides many kinds of topic to the students, as they can choose their own topic of interest.

There are many things that the students can write in dialogue journal, they can: ask the teacher questions about class material, discuss problems they may be having in the writing process, write retrospective analysis of the class, generate topics for discussion, and express personal concerns (Peyton and Reed in Reid, 1993, p.163).

In addition, as a private conversation with the teacher, in dialogue journal students can ask questions, complain about the lessons, tell what happened in and outside the class, reflect on why things happen, 
express personal feelings, so "they use the written language in all the purposeful ways they use their spoken language" (Staton, 1987).

Dialogue journal can improve students' motivation in writing through the freedom of choosing a topic to write (Liao \& Wong, 2010; Bolton, 2013). They can choose a topic that interests them most. One of the best sources of a good topic for the students to write is the students themselves and their interest (Raimes, 1983, p. 15). Moreover, the students, in writing dialogue journal, do not have to focus on correct forms, so they can freely and openly deliver their ideas of their topic of interest (Liao \& Wong, 2010). As their motivation increases, the feeling of worry reduces. In this case, the students are not afraid in making mistake. Thus dialogue journal has proven able to reduce anxiety in writing (Liao \& Wong, 2010; Forouton \& Noordin, 2012).

Furthermore, by writing Dialogue journal frequently, the students' writing proficiencies will improve as they go along the process (Liao \& Wong, 2010; Naba'h, 2013; Mehrdad, 2008; Forouton, Noordin \& Hamzah, 2013). Through regular practices, dialogue journal can build students' fluency on writing.

There are several advantages of writing dialogue journal. Garmon (2001) investigated the benefit and drawbacks of dialogue journal writing. He analyzed the students evaluative comments and categorize them into six major subcategorize benefits and two subcategories drawbacks of Dialogue Journal. The benefits are: (1) Facilitating learning of course material; (2) Promoting self-reflection and selfunderstanding; (3) Procedural conveniences and benefits; (4) Opportunity to express ideas; (5) Getting feedback on ideas and questions; (6) Improving the teacher-student relationship. While the drawbacks are: (1) journal requirements and procedures, and (2) Time demands.

Another advantages and disadvantages or challenges of dialogue journal were pointed out by Peyton (2000). The advantages include: (1) Extended contact time with the learners; (2) Management of classes with learners of varying language, ability, and interest levels; (3) Assessments of the learners' needs and progress; and (4) Facilitation of language learning. The disadvantages of dialogue journal are: (1) Correctness of the writing; (2) Facilitation of language learning; and (3) Writing that is overly personal.

This article aims at reporting a study on the use of Dialogue journal to improve the writing proficiency of the students of class VIIIG of SMP Negeri 14 Surakarta.

\section{RESEARCH METHODOLOGY}

This study was a classroom action research. The study was conducted in class VIIIG of one of state junior high school in Surakarta. There were 20 students who participated in the research. The research was divided into three sections, namely preresearch, research, and post-research.

The pre-research was conducted to identify the students' problems in writing and the classroom situation. There were three activities in the pre-research: observation, interview and pre-test. In the observation, the researcher observed the teaching and learning processes led by the English teacher. The researcher monitored the teaching technique used by the English teacher and the students' behavior during the lesson. After that, the researcher began to interview the English teacher and two 
students. It was aimed at obtaining information verbally according to the respondents' perspective. Finally, the students were required to do a pre-test to get the actual information about their problem in writing skill. The reason of doing preresearch was to construct problem indication, problem formulation and problem solution. After the problems were identified and formulated, the researcher began to design the research.

The researcher designed the research by considering the students' problems in writing and the classroom situation found in the pre-research. The research was divided into two cycles. Each cycle consisted of four meetings. The three meetings were used for the learning processes and the last meeting was used for conduct a post-test. Each cycle went through four phases: plan, act, observe and reflect. Dialogue journal was implemented in the lesson plan as a practice for the students in writing. The text type the students had to write was recount text. After the lesson plan was made; the researcher then implemented the action. The researcher played an important role as the researcher and also the teacher in the teaching and learning processes.

During the action, the researcher also conducted an observation. The objective of the observation was to monitor all events and activities that happened during the teaching and learning processes, such as the students' behavior and the students' writing performance. The researcher recorded them in the form of field notes. The field notes were written in a notebook. In the last meeting of every cycle, the researcher conducted a post-test which was used to measure the effect of dialogue journal to the students' writing performance.
Finally, the researcher made a reflection in the end of each cycle. The researcher reviewed and evaluated all actions that had been implemented. It involved the activity of the finding the strengths and weaknesses of the action as a source for re-planning the next cycle if the result was not satisfied.

The data collected in this research were categorized into qualitative and quantitative data. The qualitative data were obtained from observations and interviews. While the quantitative data were gained from the students' tests include pre-test and post-test. After all the data were collected, the researcher then analyzed the data using interactive model of analyzing data introduced by Miles and Huberman (1992) for the qualitative data. The interactive model consists of three steps which are: data reduction, data display and conclusions drawing/ verifying. While quantitative data were analyzed using Descriptive Statistic.

\section{FINDINGS AND DISCUSSION}

The data obtained from the preresearch were the students' problems in writing and the classroom situation. The findings of the pre-research indicate that the students' problems in writing are: 1) they had difficulties in shaping their ideas; (2) they lacked vocabulary mastery which made them difficult to make right word choices; (3) they also had problems in spelling - they usually misspelled some words; (4) they had difficulties in mechanics and punctuations they barely used a period to end their sentences; (5) they had difficulties in differentiating tenses - some students used simple present tenses for past situations; and (6) they had problems in differentiating word classes - they had problems in differentiating verbs and adjectives. 
Furthermore, there were several problems dealing with the classroom situation: (1) there were monotonous activities; (2) the students' motivation was low in following the lessons; (3) the students-teacher relationship was not good because the lack of the students-teacher interaction; and (4) there was no activity dealing with writing skill development. Those problems arose because the teaching technique used by the teacher was too technical, the students' intrinsic motivation was low and there was no variation of the teaching media used by the teacher.
The result of the pre-test showed that the students' writing performance was low. Their mean score in the pre-test was 69.95 from the passing grade (72). The highest score was 80 and the lowest score was 64 . There were just seven out of twenty students who passed the passing grade. The scores were determined based on the aspects of writing: content, vocabulary, organization, grammar, and mechanics. The students' major problem was grammar. The chart below presents the students' writing mean score for each aspect of writing.

Table 1. Students' Mean Score Per-aspect in Pre-test

\begin{tabular}{clcc}
\hline No. & Aspect of Writing & Mean Score & Maximum Score \\
\hline 1. & Organization & 14,65 & 20 \\
2. & Content & 13,85 & 20 \\
3. & Grammar & 12,35 & 20 \\
4. & Mechanics & 14,7 & 20 \\
5. & Vocabulary & 14,35 & 20 \\
\hline
\end{tabular}

Based on the table above, it is indicated that the students' writing skill was low in every aspect of writing skill. The students have major problems in grammar. In this case, the researcher wanted to improve the students' writing skill by conducting Dialogue Journal as practice for the students in writing. It was expected that it would also improve the classroom situation.

In the first meeting of the first cycle, the focus was exploration and elaboration. The researcher explained the social function, the generic structures and the language features of recount text by using power point and students' handout. The students were given an example of recount text. There was a group activity in this meeting. The students were divided into four groups. They were provided with a series of pictures. They were required to construct a recount text using the given series of pictures in one of their journal.

In the second meeting of cycle one, the focus was on elaboration. The students finished the unfinished group work in the beginning of the meeting. Then they were given ten guiding questions about how to construct a recount text which were expanded from the three guiding question in the previous meeting. The students then required to write a recount text individually in their journal. The topic was left to the students such as an exciting past experience, frightening experience, embarrassing experience, heart-warming experience and so on. In addition, the students can add a note below their text, they can ask about the material that they still do not understand, they can give personal comment about the teaching learning process, and suggest the topic or activity. After the meeting was over, 
the researcher gave feedback and comment to the students work in their journal.

The third meeting of the first cycle was focus on confirmation. The students got back their journal with the researcher's feedbacks and comments on it. The researcher then explained the use of the feedbacks and comment. Then, the students were given chance to learn and study the feedback and comment in order to revise their text.

The last meeting was used to conduct a post-test. The test was a post-test which was intended to measure the improvement students made in writing skill and to know to what extend dialogue journal improve the students' writing skill. The students were required to write a recount text about another experience that they like the most individually. The result of the post-test 1 showed that there was an improvement in the students' writing skill compared with the result of pre-test. The average writing score of the students' post-test in cycle 1 was 75.5 which increases from 69.9 (pre-test score). The table below presents the result of posttest 1 as compared to the result of pre-test.

Table 2. Students' Score in Pre-test and Post-test 1

\begin{tabular}{clcc}
\hline No. & \multicolumn{1}{c}{ Aspect of Writing } & Pre-test & Post-test 1 \\
\hline 1. & Organization & 14,65 & 14,65 \\
2. & Content & 13,85 & 15,75 \\
3. & Grammar & 12,35 & 13,2 \\
4. & Mechanics & 14,7 & 16,1 \\
5. & Vocabulary & 14,35 & 15,8 \\
\hline & Total & $\mathbf{6 9 , 9}$ & $\mathbf{7 5 , 5}$ \\
\hline
\end{tabular}

From the table above, it can be concluded that students' writing proficiencies was improved after the implementation of Dialogue Journal in Cycle 1. The result from the observation also showed that the classroom situation improved. Although the students' writing proficiencies and the classroom situation were improved, still the researcher found unsolved problem in the first cycle, those are: First, Since Dialogue Journal is not concerned with forms and grammar, the researcher did not give much attention to the students' grammar. There were no activities dealing with grammar competency. Therefore, the lowest aspect the students reached was grammar.

Second, the students were passive in reading and then learning the feedbacks given by the researcher. That caused the students unaware of their mistakes and unable to correct their mistakes on their journal. This problem was identified arose because of the limitation of the feedback given by the researcher. The researcher only gave feedback in the written form. The last was the students' willingness to practice writing. They tended to postpone their process and did improper things like chatting in the middle of writing and so on. Some students complained when they were required to start writing. Those conditions were caused by the students' low motivation.

To overcome those problems, the researcher revised the lesson plan in cycle 1 . The revised plans were: First, The researcher gives more attention to the 
students' grammar and gives adequate exercises about grammar. Second, the researcher monitors the students when they read and study their feedback intensively and gives feedback and comment orally to the whole class. The last was the researcher gives clear explanation about the concept of Dialogue Journal and its benefit and motivate encourage the students orally and written in their journal.

Then, the researcher implemented the revised plan in cycle 2 . In the first meeting, the focus was on exploration and elaboration. The students watch a video about the example of recount text and analyzed it. They were also given adequate exercises dealing with grammar such as the use of simple past tenses; the use of countable and uncountable nouns; and the use of plural and singular nouns.

The second meeting was focused on elaboration. The students were given a variation of topic from their favorite song. They were required to write a recount text according to their favorite song in their journal individually. The students were freely to choose their topic to write. They can add a note to express their idea like before. After the second meeting, the researcher gave feedback and comment to the students work in their journal one by one. There were still some students who made mistakes in their writing, but it was less than before. The researcher gave correction on their grammar mistakes if it is needed. She also gave comment about the content of the story and motivates them.

The third meeting was focused on confirmation. The students got back their journal with the feedbacks and comments from the researcher. The students were given time to revise their work. The researcher gave them motivation to revise their text. While the students were working on their revision, the researcher monitored the students' work intensively.

The last meeting was to conduct a post-test. Post-test was intended to measure the students' improvement in writing skill after all the teaching and learning processes has been implemented. The result of the post-test showed that the students writing skill in all aspects improved. The students' average writing score was 79.7. The highest score was 93 and the lowest score was 69. There was still one student who did not pass the passing grade (72). The table below showed the students score from pre-test to post-test 2.

Table 3. Students' Score in Pre-test, Post-test 1, and Post-test 2

\begin{tabular}{|c|c|c|c|c|}
\hline No. & Aspect of Writing & Pre-test & Post-test 1 & Post-test 2 \\
\hline 1. & Organization & 14,65 & 14,65 & 16,2 \\
\hline 2. & Content & 13,85 & 15,75 & 15,95 \\
\hline 3. & Grammar & 12,35 & 13,2 & 14,9 \\
\hline 4. & Mechanics & 14,7 & 16,1 & 16,3 \\
\hline 5. & Vocabulary & 14,35 & 15,8 & 16,35 \\
\hline & Total & 69,9 & 75,5 & 79,7 \\
\hline
\end{tabular}

that the students' writing score was improved from pre-test to post-test 2 . It is improvement. The students' writing score were somehow decreased or same with the 
score before. However, the decline is not significant. In general, their writing score improved.

Furthermore, the classroom situation was also improved after implementing dialogue journal. The table below describes the improvement of the classroom situation before the research, in the cycle 1 and in the cycle 2 .

Table 4. Findings of the Classroom Situation during the Research

Before the Research
Cycle 1

It can be concluded that the implementation of Dialogue journal can improve the students' writing proficiencies and also the classroom situation. The researcher has found the conditions for implement Dialogue Journal effectively to improve students' writing skill. The considerations should be taken into account in implementing Dialogue Journal as regular practices for the students in writing.

First, there should be a clear explanation about the concept of Dialogue Journal to the students. They need it in order to know what Dialogue Journal is, why should they write it and how to write it. The process will go smoothly if the students know what they should do about Dialogue Journal. In this case, the teacher's job is to make sure that the students understand the concept and guide them in the process. She should emphasizing the benefits of Dialogue
Journal that gives chances for them to practices writing regularly and having a written conversation with the teacher. So, the students will aware the importance of Dialogue Journal and gave effort in writing their journal.

Second, the students need an interesting guideline to start writing. They might not have the strategies in constructing a particular text. The teacher should provide them with a clear and interesting guideline in constructing a text. She can teach them step to step start from inspiring a topic into a main idea and then developing paragraph according to main idea into the whole text. The teacher should make sure that the students will easily understand the guidelines and use it in writing a text in their journal. In first time, they might not have an idea for their text. An interesting topic is a starter so that their motivation increases. 
Then, the teacher should provide the students with guidelines to develop the content and the whole text. If the students do not have the strategy in developing the text, they will be confused in starting writing.

Third, the teacher should give adequate grammar practices. Basically, Dialogue Journal do not give concern to the form and grammar, it is just focused on fluency and communication but it cannot be neglected that grammar plays an important role on building students' writing skill. Moreover, grammar is one aspect of writing skill. Without grammar, their writing will merely out of context, their meaning were not fully delivered. According to the fact that the students' grammar competency was low from the beginning of the research, it became worse because the researcher did not put any concern about the students' grammar competency. After giving them exercises about grammar, their grammar improved as their whole writing skill improved.

Fourth, the teacher should give variety of feedback. Basically, Dialogue Journal gives chances for the teacher for giving written feedback and comment to the students' work in their journal one by one according to their specific problem. It is expected that the students will learn the feedback and know their mistakes so they can revise their writing as soon as they receive it but most of the students did not put any effort to study the feedback from the teacher. It causes they did not aware their mistakes and did not correct their mistakes. So, besides just giving a written feedback, the teacher should give another variety of feedback. The students need oral feedback intensively while they read and learn the feedback. The teacher could monitor the feedback and gives oral feedback individually for specific mistake and for the whole class.

Fifth, Dialogue Journal is a method which the students can practice writing regularly in the journal and the teacher write it back and forth. So, basically they exchange information needed for them for the needs of the students' writing skill. The students get feedback and comment for the teacher and use it in order to improve their quality of writing. While the teacher gets information about the students' need. To make sure the students use that chance appropriately, the teacher should monitor every processes took in writing Dialogue Journal intensively and emphasizing the process in writing Dialogue Journal start from the writing process itself include prewriting, writing and post writing. Then, the students' activities of learning the feedback and understand their mistake. The important thing is the students should understand the importance of the process rather than the product

The last, as regular practices for the students, both the students and the teacher should arrange time for collecting and responding the journal. If the time is clear, they can optimize the given time for writing the journal. They should have commitment to follow the time arrangement. The students should know when they should be ready to collect their journal and when to revise it. So, there is no student left behind. The teacher should give feedback and comment routinely according to the time arrangement. Then, the students can learn the feedback and revise their writing as soon as they receive it. If the time arrangement well followed, the use of Dialogue Journal as regular practices will be best implemented.

By considering the conditions above, the use of dialogue journal can be 
implemented effectively in improving the students' writing proficiencies and classroom situation. Besides that, to what extend Dialogue Journal can improve students' writing skill can be described through the numerical data based on the students' writing score. It is clear that there is significant improvement of the students' writing skill from the pre-test to the post-test 2 , in line with the improvement of all aspect of writing.

Moreover, the implementation of dialogue journal can improve the students' attitude toward the learning. They became more active and motivated in following the lesson. Students were not reluctant to ask questions to the researcher. In writing, they did not complain much to start writing.

\section{CONCLUSION AND SUGGESTION}

The results of the research show that Dialogue Journal could be implemented effectively by explaining to the students about the concept of dialogue journal and providing them with an interesting guideline to start writing. At the beginning, the students were provided with an interesting topic to begin with and then a guideline to write the whole text to attract their motivation.

In improving the writing skill, the teacher considered building the students' grammar competency included in the activities. The teacher' feedbacks were also needed by the students to know the improvement of their writing quality. The teacher monitored every process, not only focusing on the written products. A good schedule for collecting and responding the journal was important too to improve the achievement.
By implementing Dialogue Journal, the students' writing proficiency was improved. It can be seen by the improvement of their writing scores which were improved from the pre-test to post-test 2. The students' writing mean score in the pre-test was 69.9; it was improved to 75.5 in post-test 1 and 79.7 in post-test 2. The students' mean score in all aspects of writing were also improved.

Teaching writing to students was considered difficult. There are many interesting and motivating techniques in teaching writing. The teacher should choose an appropriate one which meets the students' need. He/she should create an interesting situation which covers a variety of activities for the students. Dialogue journal can be implemented in teaching writing as long as the students understand the concept of Dialogue Journal. Through dialogue journal, the teacher can build a strong relationship with the students.

In addition, the students should have bigger motivation to start writing. They should be aware that writing is important for them. The students should not be afraid of making mistakes. They should have regular practices to improve their writing. Through Dialogue Journal, the students can have regular practices in writing, also a help from the teacher's feedbacks and comments to revise their mistakes.

Furthermore, other researchers can use the result of this research as a reference to conduct a similar research to improve writing skill. They can also implement the framework used in this research in other contexts. 


\section{BIBLIOGRAPHY}

Bolton, S.D. (2013). Dialogue journal: a tool for building better writers. English teacher forum, (2). 2-11.

Brown, H.D. (2004). Language assessment: principles and classroom practices. New York: Longman.

Forouton, M., \& Noordin, N. (2012). Effect of dialogue journal writing through the use of conventional tools and e-mail on writing anxiety in the ESL context. English Language Teaching, 5(1). 1019.

Forouton, M., Noordin, N., \& Hamzah, M.S.G. (2013). How can Dialogue Journal Writing improve learners' writing performance in the English as a Second Language context? IOSR Journal Of Humanities And Social Science, 7(2). 35-42.

Garmon, M. A. (2001). The benefits of dialogue journals: What prospective teachers say. Teacher Education Quarterly, 28(4), 37-50.

Liao, M., \& Wong, C. (2010). Effects of Dialogue Journals on L2 Students' Writing Fluency, Reflections, Anxiety, and Motivation. Reflections on English Language Teaching, 9(2), 139-170.

Mehrdad, A.G. (2008). The effect of dialogue journal writing on EFL students' writing skill. The Journal of Applied Linguistics, 1(1). 34-44.

Naba'h, A. A. (2013). The Effect of Using Electronic Dialogue Journals on English Writing Performance of Jordanian Students. International Arab Journal of e-Technology, 3(1). 37-43.

Peyton, J.K. (2000). Dialogue journals: interactive writing to develop language and literacy. Retrieved from ERIC database.

Raimes, A. (1983). Technique in teaching writing: teaching techniques in English as a second language. New York: Oxford University Press.

Reid, J.M. (1993). Teaching ESL writing. New Jersey: Prentice Hall Regents.

Staton, J. (1987). Dialogue journals. Retrieved from ERIC database. 